Jurnal Inovatif Ilmu Pendidikan Vol.1 No.2, (2019), Hlm. 137-151

http://jurnal.fkip.unila.ac.id/index.php/JIIP/index

JURNAL INOVATIF

Email : inovatif.ip@fkip.unila.ac.id

\title{
Pengaruh Film Animasi adit dan Sopo Jarwo terhadap Perkembangan Moral
}

\author{
Luluk Nurmawati, Susdarwati, Arum Dwi Rahmawati \\ PG PAUD, STKIP Modern Ngawi \\ Jalan Ir Soekarno no.9 Ringroad Barat Grudo Ngawi Jawa Timur \\ E-mail: luluknurma56@gmail.com
}

\begin{abstract}
Article Info
Abstract

Received April 2019

This Objective of this research was description the effect of the animated film

Accepted Agustus 2019

Published Oktober 2019 "Adit and Sopo Jarwo" on moral development in children of group B kindergarten Dharma Wanita Gentong Paron Ngawi Academic Year 2018/2019. This research method uses pre-experimental design with onegroup type pre-test post-test design. The subjects of the study were Children of

Keywords: group $B$ of the Dharma Wanita Gentong Paron Ngawi Kindergarten, with 15 Moral Development, "Adit children consisting of 9 boys and 6 girls. Data collection techniques are and Sopo Jarwo" observation, interviews and documentation. Data analysis techniques used Animated Film parametric statistics with the $t$ test or t-test for small samples that are interconnected. The results of this study indicate that there is an increase in the average score of the moral development of children of group $B$ before and after treatment, ie 48.21 to 70.83. i.e. shows that $t_{-}($count $)=7.68$ and t_table $=2.14$ where $t_{-}$(count) $>t_{-}$tabel $(7.68>2.14)$ so that the null hypothesis $\left(H \_0\right)$ is rejected while the alternative hypothesis $\left(H \_a\right)$ is accepted. It can be concluded that there is a significant influence of the animated film "adit and sopo jarwo" on moral development in group B kindergarten children Dharma Wanita Gentong Paron Ngawi.
\end{abstract}

\begin{abstract}
Abstrak : Penelitian ini bertujuan untuk mendeskripsikan pengaruh film animasi "Adit dan Sopo Jarwo" terhadap perkembangan moral pada anak kelompok B TK Dharma Wanita Gentong Paron Ngawi Tahun Ajaran 2018/2019. Metode penelitian ini menggunakan pre-eksperimental design dengan jenis jenis onegroup pre-test post-test design. Subjek penelitian adalah Anak kelompok B TK Dharma Wanita Gentong Paron Ngawi yang berjumlah 15 anak terdiri dari 9 anak laki-laki, 6 anak perempuan. Teknik pengumpulan data observasi, wawancara dan dokumentasi. Teknik analisis data menggunakan statistik parametrik dengan uji t atau t-test untuk sampel kecil yang saling berhubungan. Hasil penelitian ini menunjukkan bahwa ada kenaikan skor rata-rata perkembangan moral anak kelompok B sebelum dan sesudah treatment atau perlakuan, yakni 48,21 menjadi 70,83 selanjutnya dengan melihat hasil perhitungan rumus t-test untuk sampel kecil yang saling berhubungan pada penelitian ini, yakni menunjukkan bahwa $t_{\text {hitung }}=7.68$ dan $t_{\text {tabel }}=2.14$ dimana $t_{\text {hitung }}>t_{\text {tabel }}(7.68>2.14)$ sehingga hipotesis nihil $\left(H_{0}\right)$ ditolak sedangkan hipotesis alternatif $\left(\mathrm{H}_{\mathrm{a}}\right.$ ) diterima. Hal ini dapat disimpulkan bahwa ada pengaruh yang signifikan film animasi "adit dan sopo jarwo" terhadap perkembangan moral pada anak kelompok B TK Dharma Wanita Gentong Paron.
\end{abstract}

Kata kunci : Perkembangan Moral, Film Animasi, Adit dan Sopo Jarwo. 


\section{PENDAHULUAN}

Pendidikan Anak Usia Dini menyebutkan bahwa Pendidikan Anak Usia Dini, yang selanjutnya disingkat PAUD, merupakan suatu upaya pembinaan yang ditujukan kepada anak sejak lahir sampai dengan usia enam tahun yang dilakukan melalui pemberian rangsangan pendidikan untuk membantu pertumbuhan dan perkembangan jasmani dan rohani agar anak memiliki kesiapan dalam memasuki pendidikan lebih lanjut. Menurut Peraturan Menteri Pendidikan dan Kebudayaan Republik Indonesia Nomor 146 Tahun 2014 pasal 1 tentang kurikulum 2013 Selanjutnya tentang Standar Nasional Pendidikan Anak Usia Dini menyebutkan bahwa Standar Tingkat Pencapaian Perkembangan Anak Usia Dini selanjutnya disebut STPPA adalah kriteria tentang kemampuan yang dicapai anak pada seluruh aspek perkembangan dan pertumbuhan, mencakup aspek nilai agama dan moral, fisikmotorik, kognitif, bahasa, sosial-emosional, serta seni.

Pendidikan karakter pada anak usia dini sesuai dengan karakteristik kurikulum 2013 Pendidikan Anak Usia Dini mencakup nilai agama dan moral. yang tercermin dalam keseimbangan kompetensi sikap, pengetahuan, dan keterampilan. Perkembangan moral merupakan perilaku yang sesuai dengan standar moral dari kelompok sosial tertentu. Pendidikan karakter pada anak usia dini sesuai dengan karakteristik kurikulum 2013 Pendidikan Anak Usia Dini mencakup nilai agama dan moral. yang tercermin dalam keseimbangan kompetensi sikap, pengetahuan, dan keterampilan. Perkembangan moral merupakan perilaku yang sesuai dengan standar moral dari kelompok sosial tertentu. Adapun bentuk-bentuk perilaku moral anak usia 5-6 tahun dalam kurikulum 2013 sebagai berikut : 1) mengenal agama yang dianut, 2) mengerjakan ibadah, 3) berperilaku jujur, penolong, sopan, hormat, sportif, dan sebagainya, 4) menjaga kebersihan diri dan lingkungan, 5) mengetahui hari besar agama, 6) menghormati (toleransi) agama orang lain. Perkembangan moral anak dapat ditandai dengan kemampuan anak untuk memahami aturan, norma, dan etika yang berlaku. Perkembangan moral adalah perkembangan yang berkaitan dengan kemampuan anak untuk mengetahui baik dan buruk suatu perbuatan dan kesadaran untuk melakukan perbuatan baik dan rasa cinta terhadap perbuatan baik. 
Bedasarkan observasi awal yang dilakukan di kelompok B TK Dharma Wanita Gentong Paron Ngawi, aspek perkembangan moral anak masih rendah. Pada saat anak dilihatkan film animasi "keluarga somat" dengan tema 1) kejujuran, 2) toleransi, dan 3) sopan santun. Sebagian besar anak masih meniru jawaban teman, Anak juga belum memiliki perilaku toleransi misalnya anak masih suka mengolokngolok teman, selain itu, anak belum memiliki perilaku sopan santun misalnya anak salim sama guru sambil lari. Film Animasi merupakan salah satu media audio visual yang memiliki banyak kelebihan. Menurut Arsyad (2011) kelebihan media audio visual tersebut antara lain:1) melengkapi pengalaman dasar anak; 2) menggambarkan suatu proses secara tepat yang dapat disaksikan secara berulang-ulang; 3) mendorong dan meningkatkan motivasi; 4) menanamkan sikap-sikap dan segi afektif lainnya; dan 5) film animasi mengandung nilai-nilai positif dapat mengundang pemikiran dan pembahasan dalam kelompok anak. Film animasi merupakan film yang menghidupkan gambar-gambar yang telah dilukis. Titik berat pembuatan film animasi adalah seni lukis. Rangkaian lukisan setiap detiknya diputar dalam proyektor film, maka lukisan-lukisan itu menjadi hidup. Saat ini banyak sekali film animasi yang mengandung hal hal kurang baik untuk perkembangan moral anak, namun tidak semua film animasi bersifat demikian. Masih ada beberapa film animasi yang megandung hal-hal baik dan mendidik untuk ditonton oleh anak anak.

Salah satu film animasi yang mendidik adalah serial animasi "adit dan sopo jarwo". Film animasi tersebut merupakan karya anak bangsa Indonesia yang patut mendapatkan apresiasi. Film Animasi “Adit dan Sopo Jarwo" perlu mendapatkan perhatian khusus karena yang ditayangkan telah diminati anak dan sesuai dengan pendidikan budaya bangsa Indonesia. Film animasi "Adit dan Sopo Jarwo" merupakan salah satu film animasi menceritakan kehidupan sehari- hari disebuah perkampungan kecil di ibu kota Jakarta, yang mencontohkan dan mengarahkan nilainilai moral dalam kehidupan sehari-hari dan layak untuk di tonton oleh anak usia dini. Film Animasi "Adit dan Sopo Jarwo" mengisahkan persahabatan antara Adit, Dennis, Mitha, dan Devi serta si mungil Adelya yang kehidupannya diwarnai petualangan tak terduga. Adit berperan sebagai penggerak, motivator, juga inspirator bagi para sahabatnya untuk melewati hari-hari dalam menggapai mimpi pada masa mendatang. Adit memiliki karakter suka mengayuh sepeda, gemar bermain, memiliki sikap 
kejujuran, toleransi dan sopan santun terhadap teman, serta lebih cerdas dibandingkan teman-temannya. Sopo dan Jarwo memiliki karakter yang kurang baik dan selalu ingin mendapat keuntungan tanpa usaha.

Film animasi "Adit dan Sopo Jarwo" merupakan salah satu film animasi yang menceritakan kehidupan sehari hari dengan tokoh Adit, Sopo dan Jarwo di sebuah perkampungan kecil di ibu kota Jakarta, yang mencotohkan dan mengarahkan nilai-nilai moral dalam kehidupan sehari hari dan layak untuk ditonton oleh anak usia dini. Berdasarkan latar belakang permasalahan di atas, penulis ingin mengetahui "Pengaruh Film Animasi "Adit dan Sopo Jarwo" Terhadap Perkembangan Moral Pada Anak kelompok B TK Dharma Wanita Gentong Paron Ngawi”.

\section{Perkembangan Moral}

Moral berasal dari bahasa Latin "mos" (jamak mores) yang berarti kebiasaan, adat. Kata "mos" (mores) dalam bahasa Latin sama artinya dengan etos dalam bahasa Yunani. Di dalam bahasa Indonesia, kata moral diterjemahkan dengan arti susila. Adapun pengertian moral yang paling umum adalah tindakan manusia yang sesuai dengan ide-ide yang diterima umum, yaitu berkaitan dengan makna yang baik dan wajar. Dengan kata lain, pengertian moral adalah suatu kebaikan yang disesuaikan dengan ukuran-ukuran tindakan yang diterima oleh umum, meliputi kesatuan sosial atau lingkungan tertentu. Kata moral selalu mengacu pada baik dan buruknya perbuatan manusia sebagai manusia. Telah banyak ahli yang mencoba memberikan pengertian moral. Berikut ini beberapa Pengertian Moral Menurut para Ahli: Pengertian Moral Menurut Wantah (2005), Moral adalah sesuatu yang berkaitan atau ada hubungannya dengan kemampuan menentukan benar salah dan baik buruk tingkah laku. Pengertian Moral Menurut Chaplin (2006), Moral mengacu pada akhlak yang sesuai dengan peraturan sosial, atau menyangkut hukum atau adat kebiasaan yang mengatur tingkah laku. Berdasarkan uraian diatas, dapat disimpulkan bahwa Moral adalah suatu keyakinan tentang benar salah, baik dan buruk, yang sesuai dengan kesepakatan sosial, yang mendasari tindakan atau pemikiran. Jadi, moral sangat berhubungan dengan benar salah, baik buruk, keyakinan, diri sendiri, dan lingkungan sosial. Perkembangan moral menurut permendikbud nomor 137 tahun 2014 meliputi mengenal agama yang dianut, mengerjakan ibadah, beperilaku jujur, penolong, sopan hormat, sportif dan sebagainya, menjaga kebersihan diri dan 
lingkungan, mengetahui hari besar agama, menghormati ( toleransi) agama oang lain. Bedasarkan uraian di atas perkembangan moral pada penelitian ini adalah perkembangan yang berkaitan dengan kemampuan anak untuk mengetahui baik dan buruk suatu perbuatan dan kesadaran untuk melakukan perbuatan baik,dan rasa cinta terhadap perbuatan baik. Dalam mempelajari perkembangan sikap moral peserta didik usia sekolah, piaget (2002) mengemukakan tiga tahap perkembangan moral sesuai dengan kajian pada aturan dalam permainan anak yaitu Fase absolut, dimana anak menghayati peraturan sebagai sesuatu hal yang mutlak, tidak dapat diubah, karena berasal dari otoritas yang dihormati (orang tua, guru, anak yang lebih berkuasa), Fase realitas, dimana anak menyesuaikan diri untuk menghindari penolakan orang lain. Dalam permainan, anak menaati aturan yang disepakati bersama sebagai suatu kenyataan/realitas yang dapat diubah asal disetujui bersama, Fase subjektif, dimana anak memperhatikan motif atau kesengajaan dalam memahami aturan dan gembira mengembangkan serta menerapkan.

Dalam kategori perkembangan moralnya, kohlberg (1995) mengemukakan tiga tingkat dengan enam tahap perkembangan moral .

1. Prakonvensional

Pada tingkat ini aturan berisi aturan moral yang dibuat berdasarkan otoritas. Anak tidak melanggar aturan moral karana takut ancaman atau hukuman dari otoritas. Tingkat ini dibagi menjadi empat tahap: (a) tahap orientasi terhadap kepatuhan dan hukuman pada tahap ini anak hanya mengetahui bahwa aturanaturan ini ditentukan oleh adanya kekuasaan yang tidak bisa diganggu gugat. Anak harus menurut, atau kalau tidak, akan mendapat hukuman. (b) tahap relativistik hedonosme pada tahap ini anak tidak lagi secara mutlak tergantung pada aturan yang berada di luar dirinya yang ditentukan orang lain yang memiliki otoritas. Anak mulai sadar bahwa setiap kejadian mempunyai beberapa segi yang bergantung pada kebutuhan (relativisme) dan kesenangan seseorang (hedonisme)

2. Konvensional

Pada tingkatan ini anak mematuhi aturan yang dibuat bersama agar diterima dalam kelompoknya. Tingkat ini juga terdiri dari dua tahap. (a) tahap orientasi mengenai anak yang baik. Pada tahap ini anak mulai memperlihatkan orientasi perbuatan yang dapat dinilai baik atau tidak baik oleh orang lain atau masyarakat. 
Sesuatu dikatakan baik dan benar apabila sikap dan perilakunya dapat diterima oleh orang lain atau masyarakat. (b) tahap mempertahankan norma sosial dan otoritas. Pada tahap ini anak menunjukkan perbuatan baik dan benar bukan hanya agar dapat diterima oleh lingkungan masyarakat di sekitarnya, tetapi juga bertujuan agar dapat ikut mempertahankan aturan dan norma/ nilai sosial yang ada sebagai kewajiban dan tanggung jawab moral untuk melaksanakan aturan yang ada.

\section{Pasca konvensional}

Pada tingkat ini anak mematuhi aturan untuk menghindari hukuman kata hatinya. Tingkat ini juga terdiri dari dua tahap. (a) tahap orientasi terhadap perjanjian antara dirinya dengan lingkungan sosial. Pada tahap ini ada hubungan timbal balik antara dirinya dengan lingkungan sosial dan masyarakat. Seseorang menaati aturan sebagai kewajiban dan tanggung jawab dirinya dalam menjaga keserasian hidup masyarakat. (b) tahap universal. Pada tahap ini selain ada norma pribadi yang bersifat subyektif ada juga norma etik (baik/buruk, benar/salah) yang bersifat universal sebagai sumber menentukan sesuatu perbuatan yang berhubungan dengan moralitas.

Teori perkembangan moral yang dikemukakan Kohlberg seperti halnya Piaget menunjukkan bahwa sikap dan perilaku moral bukan hasil sosialisasi atau pelajaran yang diperoleh dari kebiasaan yang berhubungan dengan nilai kebudayaan semata-mata. Tetapi juga terjadi sebagai akibat dari aktivitas spontan yang dipelajari dan berkembang melalui interaksi sosial anak dengan lingkungannya.

\section{Film Animasi Adit dan Sopo Jarwo}

Bahwa media audio visual yaitu media yang dapat dilihat sekaligus dapat didengar, seperti film bersuara, video, televisi, dan sound slide Sumiati (2007). Sedangkan Rusman (2012) menjelaskan bahwa media audio visual yaitu media yang merupakan kombinasi audio dan visual atau bisa disebut media pandang-dengar. Contoh dari media audio-visual adalah program video atau televisi pendidikan, video atau televisi instruksional, dan program slide suara (sound slide). Berdasarkan penjelasan di atas dapat disimpulkan bahwa media audio visual merupakan media yang dapat digunakan dalam kegiatan pembelajaran dengan melibatkan pendengaran 
dan penglihatan sekaligus dalam satu proses atau kegiatan. Contoh media audio visual adalah film, video, program TV, slide suara (sound slide) dan lain-lain. Setiap jenis media yang digunakan dalam proses pembelajaran memiliki kelebihan dan kelemahan begitu pula dengan media audio visual. Arsyad (2011) mengungkapkan beberapa kelebihan dan kelemahan media audio visual dalam pembelajaran sebagai berikut:

1. Kelebihan media audio visual:

a. Film dan video dapat melengkapi pengalaman dasar anak.

b. Film dan video dapat menggambarkan suatu proses secara tepat yang dapat disaksikan secara berulang-ulang jika perlu.

c. Di samping mendorong dan meningkatkan motivasi film dan video menanamkan sikap-sikap dan segi afektif lainnya.

d. Film dan video yang mengandung nilai-nilai positif dapat mengundang pemikiran dan pembahasan dalam kelompok siswa.

e. Film dan video dapat menyajikan peristiwa yang berbahaya jika dilihat secara langsung.

f. Film dan video dapat ditunjukkan kepada kelompok besar atau kelompok kecil, kelompok yang heterogen maupun homogen maupun perorangan.

g. Film yang dalam kecepatan normal memakan waktu satu minggu dapat ditampilkan dalam satu atau dua menit.

2. Kelemahan media audio visual:

a. Pengadaan film dan video umumnya memerlukan biaya mahal dan waktu yang banyak

b. Tidak semua siswa mampu mengikuti informasi yang ingin disampaikan melalui film tersebut

c. Film dan video yang tersedia tidak selalu sesuai dengan kebutuhan dan tujuan belajar yang diinginkan, kecuali dirancang dan diproduksi khusus untuk kebutuhan sendiri.

Berdasarkan uraian di atas dapat disimpulkan bahwa kelebihan dan kelemahan media audio visual yang berupa film dan video bukan merupakan suatu kendala dalam proses pembelajaran. 
Film kartun atau film animasi pertama kali diperkenalkan oleh Emile Cold dari Perancis pada tahun 1908. Sekarang pemutaran film kartun atau film animasi banyak didominasi oleh tokoh-tokoh buatan seniman Amerika Serikat Walt Disney, baik kisah-kisah singkat Mickey Mouse dan Donald Duck maupun feature panjang diantaranya Snow White. Menurut bahasa, kata animasi diambil dari bahasa latin "Anima" yang berarti jiwa, hidup, nyawa semangat. Animasi adalah gambar dua dimensi yang seolah-olah bergerak karena kemampuan otak untuk selalu menyimpan atau mengingat gambar yang terlihat sebelumnya. Berdasarkan uraian diatas film animasi adalah usaha untuk menggerakkan sesuatu yang tidak bisa bergerak sendiri dan diputar dalam proyektor maka gambar tersebut akan bergerak atau menjadi hidup.

Secara garis besar, animasi computer dibagi menjadi dua kategori, yaitu:

a. Computer Assisted Animation

Animasi pada kategori ini biasanya menunjuk pada system animasi 2 dimensi, yaitu mengkomputerisasi proses animasi tradisional yang menggunakan gambaran tangan. Computer digunakan untuk pewarnaan, penerapan virtual kamera dan penataan data yang digunakan dalam sebuah animasi.

b. Computer Generated Animation

Kategori ini biasanya digunakan untuk animasi 3 dimensi dengan program 3D seperti 3D Studio Max, Maya, Autocad dll.

c. Animasi Komputer

Sesuai dengan namanya, animasi ini secara keseluruhan dikerjakan dengan menggunakan komputer. Dari pembuatan karakter, mengatur gerakkan "pemain" dan kamera, pemberian suara, serta spesial efeknya semuanya di kerjakan dengan komputer. Dengan animasi komputer, hal-hal yang awalnya tidak mungkin digambarkan dengan animasi menjadi mungkin dan lebih mudah. Sebagai contoh perjalanan wahana ruang angkasa ke suatu planet dapat digambarkan secara jelas, atau proses terjadinya tsunami.

Perkembangan teknologi komputer saat ini, memungkinkan orang dengan mudah membuat animasi. Animasi yang dihasilkan tergantung keahlian yang dimiliki dan software yang digunakan. Tayangan Adit \& Sopo Jarwo merupakan film kartun yang dikategorikan ke dalam Computer Generated Animation yang 
menggunakan animasi 3 dimensi dengan program opensource Blender yang berfungsi untuk membuat animasi 3D yang menarik. Pengerjaan dipimpin oleh sutradara Dana Riza dan kurang lebih melibatkan 60 orang Animator. Gambar 3D dari animasi Adit \& Sopo Jarwo menggunakan software opensource Blender. Pengerjaan pengisian suara oleh Eltra Studio dan pengarahan dialog atas pengisian suara oleh Mardi Midorikawa.

\section{METODE}

Penelitian dilakukan pada bulan februari 2019 di TK Dharma Wanita Gentong Paron Ngawi. Penelitian ini menggunakan pre-eksperimental design dengan jenis jenis one-group pre-test post-test design. Metode pengumpulan data menggunakan metode observasi, wawancara dan dokumentasi. Teknik analisis data menggunakan statistik parametrik dengan uji t atau t-test.

\section{HASIL DAN PEMBAHASAN}

Berdasarkan hasil penelitian deskripsi data masing-masing variabel disajikan dalam bentuk tabel sebagai berikut:

Tabel 1. Perkembangan Moral Anak Kelompok B TK Dharma wanita Gentong

\begin{tabular}{|c|c|c|c|c|c|}
\hline No & Nama Anak & \multicolumn{2}{|c|}{$\begin{array}{l}\text { Perkembangan Moral } \\
\text { Anak Kelompok B TK } \\
\text { Dharma wanita Gentong }\end{array}$} & d $(x-y)$ & $\mathrm{d}^{2}$ \\
\hline 1 & FS & 50 & 66.66 & 16.66 & 277.56 \\
\hline 2 & PW & 41.66 & 58.33 & 16.67 & 277.89 \\
\hline 3 & $\mathrm{TP}$ & 58.33 & 75 & 16.67 & 277.89 \\
\hline 4 & KK & 33,33 & 75 & 41.67 & 1736.39 \\
\hline 5 & AS & 66.66 & 66.66 & 0 & 0.00 \\
\hline 6 & $\mathrm{ZK}$ & 50 & 66.66 & 16.66 & 277.56 \\
\hline 7 & $\mathrm{TS}$ & 41.66 & 75 & 33.34 & 1111.56 \\
\hline 8 & $\mathrm{AT}$ & 41.66 & 75 & 33.34 & 1111.56 \\
\hline 9 & MF & 58.33 & 75 & 16.67 & 277.89 \\
\hline 10 & $\mathrm{AZ}$ & 58.33 & 91.66 & 33.33 & 1110.89 \\
\hline 11 & SZ & 41.66 & 66.66 & 25 & 625.00 \\
\hline 12 & $\mathrm{AK}$ & 41.66 & 75 & 33.34 & 1111.56 \\
\hline 13 & DR & 41.66 & 66.66 & 25 & 625.00 \\
\hline 14 & JS & 50 & 58.33 & 8.33 & 69.39 \\
\hline \multirow[t]{3}{*}{15} & $\mathrm{AP}$ & 58.33 & 75 & 16.67 & 277.89 \\
\hline & Jumlah & 733.27 & 1066.62 & 333.35 & 9168,00 \\
\hline & & 48.21 & 70.83 & 22.62 & \\
\hline
\end{tabular}


Berdasarkan sajian data pada tabel diatas, maka harga $t_{\text {hitung dapat dicari }}$ atau dihitung menggunakan rumus t-test untuk sampel kecil yang saling berhubungan. Sebelum mencari harga $t_{\text {hitung }}$ terlebih dahulu mencari jumlah kuadrat deviasi yakni dengan perhitungan sebagai berikut:

$$
\begin{aligned}
\Sigma x^{2} \mathrm{~d} & =\Sigma d^{2}-\frac{(\Sigma d)^{2}}{N} \\
& =9168.00-\frac{(333.35)^{2}}{15} \\
& =9168.00-7408.148 \\
& =1759.85
\end{aligned}
$$

$\mathrm{Md}=\frac{\Sigma d}{N}=\frac{333.35}{15}=22.22$

Langkah berikutnya adalah mencari harga $t_{\text {hitung }}$ dengan dengan menggunakan rumus:

$$
\begin{aligned}
& \mathrm{t}=\frac{M d}{\frac{\sum x^{2} d}{N(N-1)}} \\
& =\frac{22,22}{\sqrt{\frac{1759.85}{15(15-1)}}} \\
& =\frac{22,22}{\sqrt{\frac{1759.85}{210}}} \\
& =\frac{22,22}{\sqrt{8,38}}=\frac{22,22}{2.89}=7,68
\end{aligned}
$$

Berdasarkan hasil perhitungan diatas, diketahui bahwa nilai $t_{h i t u n g}$ yang diperoleh adalah delapan koma delapan, sehingga dapat dibaca ada selisih derajat perbedaan skr subjek sebelum dan sesudah treatment atau pemberian perlakuan sebesar 7,68. Langkah selanjutnya yaitu, memberikan interpretasi terhadap

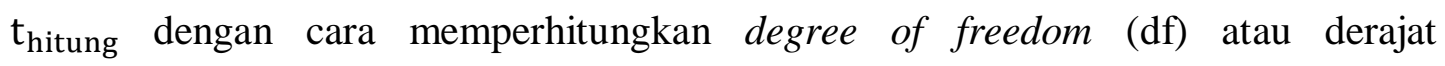
kebebasannya $(\mathrm{db})$ terlebih dahulu. Dengan itu maka perlu diperhitungkan degree of freedom (df) atau derajat kebebasan (db)dalam hal ini yakni dengan perhitungan sebagai berikut:

$$
\begin{aligned}
\mathrm{df} & =\mathrm{N}-1 \\
& =15-1 \\
& =14
\end{aligned}
$$

Degree of freedom (df) atau derajat kebebasannya (db) sebesar 14, kemudian dikonsultasikan pada tabel nilai " $t$ " dengan taraf signifikan sebesar 5\%, maka 
diperoleh harga $t_{\text {tabel }}$ sebesar 2,14. Sesudah langkah-langkah pehitungan dilakukan, maka untuk selanjutnya membandingkan antara $t_{\text {hitung }}$ dengan $t_{\text {tabel }}$. Jika $t_{\text {hitung }}>$ $\mathrm{t}_{\text {tabel }}$ maka hipotesis nihil $\left(\mathrm{H}_{0}\right)$ ditolak dan hipotesis alternatif $\left(\mathrm{H}_{\mathrm{a}}\right)$ diterima, tetapi apabila $t_{\text {hitung }}<t_{\text {tabel }}$ maka hipotesis nihil $\left(\mathrm{H}_{0}\right)$ diterima dan hipotesis alternatif $\left(\mathrm{H}_{\mathrm{a}}\right)$ ditolak. Hasil penelitian di atas, diketahui bahwa $t_{\text {hitung }}>\mathrm{t}_{\text {tabel }}(7,68>$ $2,14)$ maka hipotesis nihil $\left(\mathrm{H}_{0}\right)$ ditolak dan hipotesis alternatif $\left(\mathrm{H}_{\mathrm{a}}\right)$ diterima.

Pada setiap anak atau subjek penelitian disini memiliki kenaikan skor perkembangan moral yang berbeda-beda atau tidak sama. Perbedaan kenaikan skor tersebut disebabkan oleh tingkah laku anak setiap hari.

\section{Pengujian Hipotesis}

Berdasarkan hasil pengujian hipotesis di atas maka kesimpulan hipotesisnya adalah Keputusan Uji Hipotesis : $\mathrm{H}_{0}$ ditolak dan $\mathrm{H}_{\mathrm{a}}$ diterima. Simpulan Hasil Uji Hipotesis membuktikan bahwa Ada pengaruh film animasi "adit dan sopo jarwo terhadap perkembangan moral pada anak kelompok B TK Dharma Wanita Gentong Paron Ngawi.

\section{PEMBAHASAN}

Berdasarkan simpulan pengujian hipotesis diatas maka dapat dibahas hal-hal sebagai berikut: Berdasarkan hasil pengujian hipotesis diketahui bahwa $\mathrm{H}_{0}$ ditolak dan $\mathrm{H}_{\mathrm{a}}$ diterima. Ini berarti bahwa Ada pengaruh film animasi "adit dan sopo jarwo" terhadap perkembangan moral pada anak kelompok B TK Dharma Wanita Gentong Paron Ngawi. Media audio visual merupakan salah satu jenis media pembelajaran yang dapat digunakan dalam proses pembelajaran. Asyhad (2011) mendefinisikan bahwa media audio visual adalah jenis media yang digunakan dalam kegiatan pembelajaran dengan melibatkan pendengaran dan penglihatan sekaligus dalam satu proses atau kegiatan. Pesan dan informasi yang dapat disalurkan melalui media ini dapat berupa pesan verbal dan nonverbal yang mengandalkan baik penglihatan maupun pendengaran. Beberapa contoh media audio visual adalah film, video, program TV dan lain-lain. Melalui media audio visual, akan lebih mudah untuk menyampaikan pembelajaran yang berkaitan dengan perkembangan moral anak menggunakan film animasi. Film animasi merupakan film yang menghidupkan gambar-gambar yang telah dilukis. Titik berat pembuatan film animasi adalah seni 
lukis. Rangkaian lukisan setiap detiknya diputar dalam proyektor film, maka lukisanlukisan itu menjadi hidup. Saat ini banyak sekali film animasi yang mengandung hal hal kurang baik untuk perkembangan moral anak, namun tidak semua film animasi bersifat demikian. Masih ada beberapa film animasi yang megandung hal-hal baik dan mendidik untuk ditonton oleh anak anak. Salah satu film animasi yang mendidik adalah serial animasi "adit dan sopo jarwo". Untuk meningkatkan perkembangan moral anak, peneliti menggunakan film animasi "adit dan sopo jarwo" sebagai alat bantu untuk menyampaikan pembelajaran. Dengan adanya film animasi "adit dan sopo jarwo" pembelajaran yang akan disampaikan dapat terlaksana dengan baik. Dalam kehidupan sehari-hari perilaku moral anak masih sangat rendah, untuk itu pembelajaran moral harus di utamakan ketika dirumah ataupun disekolahan. Piaget menunjukkan bahwa sikap dan perilaku moral bukan hasil sosialisasi atau pelajaran yang diperoleh dari kebiasaan yang berhubungan dengan nilai kebudayaan sematamata. Tetapi juga terjadi sebagai akibat dari aktivitas spontan yang dipelajari dan berkembang melalui interaksi sosial anak dengan lingkungannya. Melihat film animasi tidak membuat anak merasa jenuh, pembelajaran yang akan disampaikan dapat terlaksana secara optimal. Peneliti yakin bahwa dengan melihat film animasi "adit dan sopo jarwo" dapat membantu keefektifan proses pembelajaran, selain itu mengingat karakteristik anak mudah bosan atau lebih sering tertarik pada hal baru maka film animasi "adit dan sopo jarwo" perlu di coba untuk diaplikasikan pada pengajaran taman kanak- kanak, sehingga anak dapat memfokuskan diri (memperhatikan secara penuh) serta tertarik atau termotivasi untuk mengikuti kegiatan belajara mengajar. Hal ini diperkuat dengan penelitian yang relevan yang ditulis oleh Arsita (2014) dengan judul "Pengaruh Tayangan Film Terhadap Pola Tingkah Laku Anak Usia Sekolah Dasar”. Yang menunjukkan simpulannya bahwa Film animasi memberikan pengaruh terhadap tingkah laku anak. berarti Pemaparan teori-teori diatas, dapat diartikan bahwa penelitian ini sesuai dengan teori-teori yang telah dikemukakan atau dibahas dengan kata lain teori-teori inipun dapat diterima atau dapat dijadikan acuan yang tepat dalam penelitian ini. Hal ini merujuk pada pemaparan teori-teori diatas serta melihat dari hasil penelitian ini yakni $t_{\text {hitung }}>$ $t_{\text {tabel }}(7,68>2,14)$ sehingga hipotesis nihil $\left(\mathrm{H}_{\mathrm{o}}\right)$ ditolak dan hipotesis alternatif $\left(\mathrm{H}_{\mathrm{a}}\right)$ diterima, artinya bahwa adanya pengaruh yang berarti atau secara signifikan tentang 
Film animasi "adit dan sopo jarwo" terhadap perkembangan moral pada anak kelompok B TK Dharma Wanita Gentong Paron Ngawi, bahwa Ada pengaruh film animasi "adit dan sopo jarwo" terhadap perkembangan moral pada anak kelompok B TK Dharma Wanita Gentong Paron Ngawi. Media audio visual merupakan salah satu jenis media pembelajaran yang dapat digunakan dalam proses pembelajaran. Asyhad (2011) mendefinisikan bahwa media audio visual adalah jenis media yang digunakan dalam kegiatan pembelajaran dengan melibatkan pendengaran dan penglihatan sekaligus dalam satu proses atau kegiatan. Pesan dan informasi yang dapat disalurkan melalui media ini dapat berupa pesan verbal dan nonverbal yang mengandalkan baik penglihatan maupun pendengaran. Beberapa contoh media audio visual adalah film, video, program TV dan lain-lain. Melalui media audio visual, akan lebih mudah untuk menyampaikan pembelajaran yang berkaitan dengan perkembangan moral anak menggunakan film animasi. Film animasi merupakan film yang menghidupkan gambar-gambar yang telah dilukis. Titik berat pembuatan film animasi adalah seni lukis. Rangkaian lukisan setiap detiknya diputar dalam proyektor film, maka lukisanlukisan itu menjadi hidup. Saat ini banyak sekali film animasi yang mengandung hal hal kurang baik untuk perkembangan moral anak, namun tidak semua film animasi bersifat demikian. Masih ada beberapa film animasi yang megandung hal-hal baik dan mendidik untuk ditonton oleh anak anak. Salah satu film animasi yang mendidik adalah serial animasi "adit dan sopo jarwo"

\section{KESIMPULAN}

\section{Simpulan}

Berdasarkan pada tujuan serta analisis data dari penelitian ini terbukti bahwa ada kenaikan skor rata-rata perkembangan moral anak kelompok B sebelum dan sesudah treatment atau perlakuan, yakni 48,21 menjadi 70,83 selanjutnya dengan melihat hasil perhitungan rumus t-test untuk sampel kecil yang saling berhubungan pada penelitian ini, yakni menunjukkan bahwa bahwa $t_{\text {hitung }}=7.68$ dan $t_{\text {tabel }}=2.14$ dimana $t_{\text {hitung }}>t_{\text {tabel }}(7.68>2.14)$ sehingga hipotesis nihil $\left(\mathrm{H}_{0}\right)$ ditolak sedangkan hipotesis alternatif $\left(\mathrm{H}_{\mathrm{a}}\right)$ diterima. Hal ini dapat disimpulkan bahwa ada pengaruh yang signifikan film animasi "adit dan sopo jarwo" terhadap perkembangan moral pada anak kelompok B TK Dharma Wanita Gentong Paron. 


\section{Saran}

Berdasarkan hasil penelitian, peneliti mengemukakan beberapa saran sebagai berikut:

1. Bagi Anak

Anak lebih aktif dalam proses pembelajaran yang lebih bermakna, menyenangkan sesuai taraf perkembangannya.

2. Bagi Guru

Dengan adanya penelitian ini bisa menjadi umpan balik untuk memperbaiki perkembangan moral anak melalui film animasi "Adit dan Sopo Jarwo".

3. Bagi Sekolah

Memberikan pendidikan moral dengan baik salah satunya melalui film animasi “Adit dan Sopo Jarwo".

\section{DAFTAR PUSTAKA}

Arsyad. (2011). Media Pembelajaran. Jakarta: PT Raja Grafindo Persada. Sumiati, Asra. (2007). Metode Pembelajaran. Bandung: CV.Wacana Prima.

Chaplin J P. (2006). Kamus Lengkap Psikologi. Jakarta: PT. Raja Grafindo Persada. Kohlberg. (1995). Tahap-tahap Perkembangan Moral, Yogyakarta: Kanisius Arsita, Melvi. (2014). Pengaruh Tayangan Film Kartun Terhadap Pola Tingkah Laku Anak Usia Sekolah Dasar di Lingkungan ll Kelurahan Gunung Terang Bandar Lampung. (Diakses tanggal 19 Desember 2018).

Peraturan Menteri Pendidikan dan Kebudayaan Republik Indoesia Nomor 137 Tahun 2014. tentang Standar Naional Pendidikan Anak Usia Dini.Jakarta:Kemdikbud.

Peraturan Menteri Pendidikan dan Kebudayaan Republik Indoesia Nomor 146 Tahun 2014. tentang Kurikulum 2013 Pendidikan Anak Usia Dini. Jakarta:Kemdikbud

Piaget, Jean. (2002). Tingkat Perkembangan Kognitif. Jakarta: Gramedia Rusman. (2012). Belajar dan Pembelajaran Berbasis Komputer Mengembangkan Profesionalisme Guru Abad 21. Bandung: Alfabet 
Wantah. (2005). Pengembangan disiplin dan pembentukan moral pada anak usia dini, Jakarta: Departemen Pendidikan Nasional Direktoret Jendral Pendidikan Tinggi Direktorat Pembinaan Pendidikan Tenaga Kependidikan Dan Ketenagaan Perguruan Tinggi. 